All existing chapters have been completely revised and new sections have been added on the use of antibiotics in infective lesions, cross finger flaps for acute injuries, reconstruction of the damaged thumb, burns of the hand and arm, and a valuable section on the surgery of rheumatoid arthritis. In addition there are over 200 new illustrations.

Its size and price ( 7 guineas) may put it beyond the reach of many who would wish to possess it, but as a work of reference it could hardly be bettered, and it can be recommended without reserve.

\section{HAROLD Bolton}

X-Rays: Their Origin, Dosage, and Practical Application, 7th ed. (Pp. vii $+331 ; 339$ illustrations, 42s.) Bristol: John Wright. 1956.

This well-known textbook has been enlarged and now includes an excellent section on industrial radiography. It was originally published as an introduction to basic and radiation physics and $x$-ray apparatus construction; these chapters are comprehensive and with the aid of the diagrams and illustrations it is possible to obtain a good understanding of the fundamentals of $x$-ray physics, but the style of writing is " chatty" and often confusing.

The chapters on film technique and diagnosis are too general and require revision to bring them up to date; the serious reader would be well advised to refer to more experienced writers in these subjects. On page 200 , it is stated " in medical radiography the density (photographic) is always very low-well below 1." Actually in chest radiography the density range is $0 \cdot 3-1 \cdot 5$. The factors given in the exposure table (page 239) should be used with caution, especially the suggestion of using focal-film distance of 27 in. for bone radiography. Silver recovery by precipitation (page 211) is impracticable, and no mention is made of the modern method of electrolỳsis now in use in most large departments. On page 287 macroradiography is described under the heading of " microradiography".

The tables at the end of the book are very useful but few radiologists would agree that chest screening (Table 18) may be carried out for a maximum of up to 60 minutes per three-week period. The inclusion of a bibliography would be helpful. The book can be highly recommended for the sections on basic and radiation physics, therapy, and $x$ rays in industry. The chapters on the practical applications in the medical field require drastic revision. It is very well nroduced; the excellent illustrations contribute much to ihe value of this edition.

\section{William G. Clarke}

\section{Books Received}

(Review in a later issue is not precluded by notice here of books recently received.)

Expert Committee on Professional and Technical Education of Medical and Auxiliary Personnel: Third Report. World Health Organization Technical Report Series No. 109. (Pp. 19. 1s. 9d.) London: H.M. Stationery Office; Geneva: World Health Organization. 1956.
La Lutte Contre L'Incendie dans les Ateliers de Nettoyage à Sec Utilisant des Solvents Inflammables. By A. Vallaud and P. Salmon. (Pp. 96; 13 figures. Free.) Paris: Institut National de Securité, 9, Avenue Montaigne, Paris, VIIIè. 1956.

Lavorazioni che Espongono all'azione della Naftalina Omologhi-Naftoli e Naftilammine-Derivati AlogenatiSolfonati e Nebrati della Naftalina ed Omologhi. By Raffaela Guiliano and Mario Rafanelli. (Pp. $100+$ index; illustrated. No price given.) Rome: Istituto Nazionale per l'Assicurazione contro gli Infortuni sul Lavoro. 1956.

Sicherheit und Gesundheit im Betrieb bei Transport und Verkehr. (Verhandlungen der Deutschen gesellschaft für Arbeitsschutz, Vol. 4.) Edited by E. Mager, W. Mutschler, and H. Steeg. (Pp. viii $+308 ; 104$ figures. DM 25.-.) Darmstadt: Verlag Dr. Dietrich Steinkopff. 1956.

Manual of Industrial Medicine, 3rd ed. By Lemuel C. McGee. (Pp. $\mathrm{x}+212$. 24s.) London: Oxford University Press. 1956.

A Short History of Public Health. By C. Fraser Brockington. (Pp. vii +235 . 15s.) London: J. \& A. Churchill. 1956.

The Treatment of Fractures, Vol. I. By Lorenz Böhler. (Pp. xxxii $+1072 ; 1527$ figures. \$24.50.) New York: Grune \& Stratton. 1956.

Annual Report 1955-56. (Pp. 259. 5s.) London: British Standards Institution. 1956.

The Bencard Manual of Allergy. (Pp. 95; illustrated. Free.) London: C. C. Bencard. 1956.

Chronicle of the World Health Organization, Vol. 10, No. 8, August, 1956. (Pp. 39; 6 figures. 1s. 9d.) Geneva: World Health Organization.

The Nuffield Foundation Eleventh Report. (Pp. 160.

Free.) London: The Nuffield Foundation. 1956.

Atti del $\mathrm{XX}^{\circ}$ Congresso Nazionale di Medicina del Lavoro, Padova-Venezia, 22-25 Sept., 1955. (Pp. Xxv +865 ; illustrated. L. 4,000.-.) Milan: Arnoldo Mondadori. 1955.

Médecine du Travail, 2nd ed. Edited by Prof. C. Simonin in collaboration with various authors. (Pp. xii +1406 ; 326 figures. Fr. frs. 6,800.-.) Paris: Librarie Maloine. 1956.

Urology and Industry. By Leonard Paul Wershub. (Pp. xviii + 151. 37s. 6d.) Oxford: Blackwell; Springfield, Illinois: Charles C. Thomas. 1956.

A Textbook of Psychiatry, 8th ed. By Sir David Henderson and the late R. D. Gillespie. (Pp. xii +746 . 35s.) London: Oxford University Press. 1956.

The Adaptation of Recreational Activities for Men in the Rehabilitation of Lower Limb Injuries. By Veida b?rclay. (Pp. ix +154 ; illustrated. 18s. 6d.) London: G. bill \& Sons. 1956.

First $i$ id in Coal Mines, 3rd ed. (Pp. 126; 21 figures. 2s. 3d.) London : The St. John Ambulance Association. 1956.

The Slough Industrial Health Service: Ninth Annual Report 1955-56. (Pp. 36. 2s.) Windsor: Oxley \& Son. 1956. 